\title{
Natural Radioactivity in Water and Its Potential Human Health Risk in the Vicinity of Mkuju River Uranium Project in Tanzania
}

\author{
Firmi P. Banzi, Peter K. Msaki, Najat K. Mohammed \\ Department of Physics, University of Dar es Salaam, Dar es Salaam, Tanzania
}

Email address:

fpbanzi@yahoo.com (F. P. Banzi)

\section{To cite this article:}

Firmi P. Banzi, Peter K. Msaki, Najat K. Mohammed. Natural Radioactivity in Water and Its Potential Human Health Risk in the Vicinity of Mkuju River Uranium Project in Tanzania. International Journal of Environmental Protection and Policy. Vol. 4, No. 5, 2016, pp. 111-119. doi: $10.11648 /$ j.ijepp.20160405.11

Received: July 29, 2016; Accepted: August 11, 2016; Published: August 29, 2016

\begin{abstract}
Consistent with best practices in uranium mining, the collection and use of site characterisation data are indispensable to ensure compliance with regulations. To comply with this requirement, two samples from each of the 47 locations were collected in an area of about $1300 \mathrm{~km}^{2}$ in the vicinity and concession area of the Mkuju River Project. The samples were analysed for radioactivity using alpha spectrometry. The activity concentrations were used to estimate health risks attributable to the consumption of drinking water containing radionuclides. The range of activity concentrations $\left(\mathrm{mBqL}^{-1}\right)$ were much higher in groundwater collected from the concession area for ${ }^{238} \mathrm{U}(79.89$ to 87.06$),{ }^{234} \mathrm{U}(79.44$ to 88.38$)$, ${ }^{226} \mathrm{Ra}$ (41.61 to 59.07 ), ${ }^{232} \mathrm{Th}\left(5.32\right.$ to 9.41 ), and ${ }^{228} \mathrm{Ra}$ (3.98 to 8.59) than in groundwater for ${ }^{238} \mathrm{U}$ (20.61 to 47.21$),{ }^{234} \mathrm{U}$ (21.70 to $49.10),{ }^{226} \mathrm{Ra}(16.80$ to 43.45$),{ }^{232} \mathrm{Th}(0.12$ to 2.80$)$, and ${ }^{228} \mathrm{Ra}(0.10$ to 2.43$)$, and surface water for ${ }^{238} \mathrm{U}$ (17.33 to 27.24$),{ }^{234} \mathrm{U}$ (21.06 to 34.43$),{ }^{226} \mathrm{Ra}(15.00$ to 25.61$),{ }^{232} \mathrm{Th}(0.16$ to 2.10$)$, and ${ }^{228} \mathrm{Ra}(0.12$ to 1.99$)$ collected in the vicinity of the project. The calculated annual effective doses and carcinogenic risks resulting from the activity concentrations in drinking water were relatively marginal, since the activity concentrations were lower than the WHO permissible limits for drinking water. These findings suggest that the water resources at MRP are safe. Thus, since this study was conducted before mining activities, these data can be used as a baseline for monitoring potential future water pollution around the Mkuju River Project.
\end{abstract}

Keywords: Baseline, Radioactivity, Mkuju River Project, Water Pollution

\section{Introduction}

The presence of radionuclides of natural origin in pristine water is of little radiological concern to a local population compared to the potential for anthropogenic radionuclide concentrations added to water sources from sources such as mineral extraction [1], emissions from the nuclear industry [26], oil and natural gas production [7], combustion of coal and other fuels [8], and use of phosphate fertilizer in farming [911]. The most common radionuclides that result in increased activity concentrations in water are those with high linear energy transfer, which are alpha-emitting radionuclides from the uranium $\left({ }^{238} \mathrm{U}\right)$ and thorium $\left({ }^{232} \mathrm{Th}\right)$ decay series. As a result of their long half-lives and solubility in water, ${ }^{238} \mathrm{U},{ }^{234} \mathrm{U},{ }^{228} \mathrm{Ra}$ ' ${ }^{226} \mathrm{Ra},{ }^{222} \mathrm{Rn}$, ${ }^{210} \mathrm{Po}$, and ${ }^{232} \mathrm{Th}$ are the main radionuclides from the ${ }^{238} \mathrm{U}$ and ${ }^{232} \mathrm{Th}$ decay series, in addition to ${ }^{235} \mathrm{U}$, that contribute to the activity concentrations in water bodies and the associated risk to biological systems that are exposed to the water [12-13]. Because removal of radionuclides from water can have substantial cost implications, it is crucial to distinguish between radionuclides of natural origin and those arising as technological by-products.

To ensure that the radiological risks associated with increased radioactivity in water caused by uranium mining are assessed and that the risk is minimised according to international safety standards [14-15], uranium-producing countries have enacted regulations to address three key issues: (i) minimisation of public concerns about potential water pollution during and after the mining operations, (ii) effective intervention to restrict discharge of radionuclides to ground or surface water, and (iii) effective means to verify compliance with regulatory limits. In line with the above initiatives, drinking water quality in 
Tanzania is regulated by TAEC [16] under the Atomic Energy Act [17]. However, it is also recognised that effective verification of compliance with regulations in the emerging uranium mining industry requires establishment of baseline radioactivity concentration data in water prior to commencement of mining. Consistent with best practices, the collection, availability, and use of site characterisation data in Tanzania is indispensable to ensure the successful implementation of site surveillance programs and remediation after cessation of uranium mining operations. Therefore, this study was conducted to establish a baseline of radiological data for water samples for the Mkuju River Project (MRP).

\section{Materials and Methods}

\subsection{Study Area}

The MRP shown in Figure 1, is a large scale uranium development project located in the Namtumbo district in the Ruvuma region between latitudes $9^{\circ} 59^{\prime} 50^{\prime \prime}$ to $10^{\circ} 07^{\prime} 15^{\prime \prime} \mathrm{S}$ and longitudes $36^{\circ} 30^{\prime} 00^{\prime \prime}$ to $36^{\circ} 37^{\prime} 55^{\prime \prime} \mathrm{E}$. This area hosts a viable uranium deposit in sandstone of about 25,200 tU. The annual production is estimated to be $1,600 \mathrm{tU}^{-1} \mathrm{r}^{-1}$ at maximum capacity over a minimum period of 12 years [18]. Because the uranium ore is present at shallow depths, conventional open-pit methods utilising mid-size earth moving equipment will be used. We have estimated the study area to be about $1300 \mathrm{~km}^{2}$ within the project's perimeter using AERMOD dispersion model, as described previously [19]. The weather pattern that most likely influences pollution of water in this area is characterised by two major seasons. The first is a rainy season, which commences in January and ends in April with an average rainfall of $70 \mathrm{~mm}$ and temperatures ranging from 11 to $29^{\circ} \mathrm{C}$. The second is a dry season, which commences in May and ends in December with temperatures ranging from 14 to $37^{\circ} \mathrm{C}$. We used an average wind speed of $6 \mathrm{~ms}^{-1}$, with a maximum wind speed of $13 \mathrm{~ms}^{-1}$ to the northeast and north and a minimum wind speed of $2 \mathrm{~ms}^{-1}$ to the southwest and south, to demarcate the study area. Since the MRP is located in a national park, the water from this location is expected to represent naturally occurring baseline radionuclide concentrations.

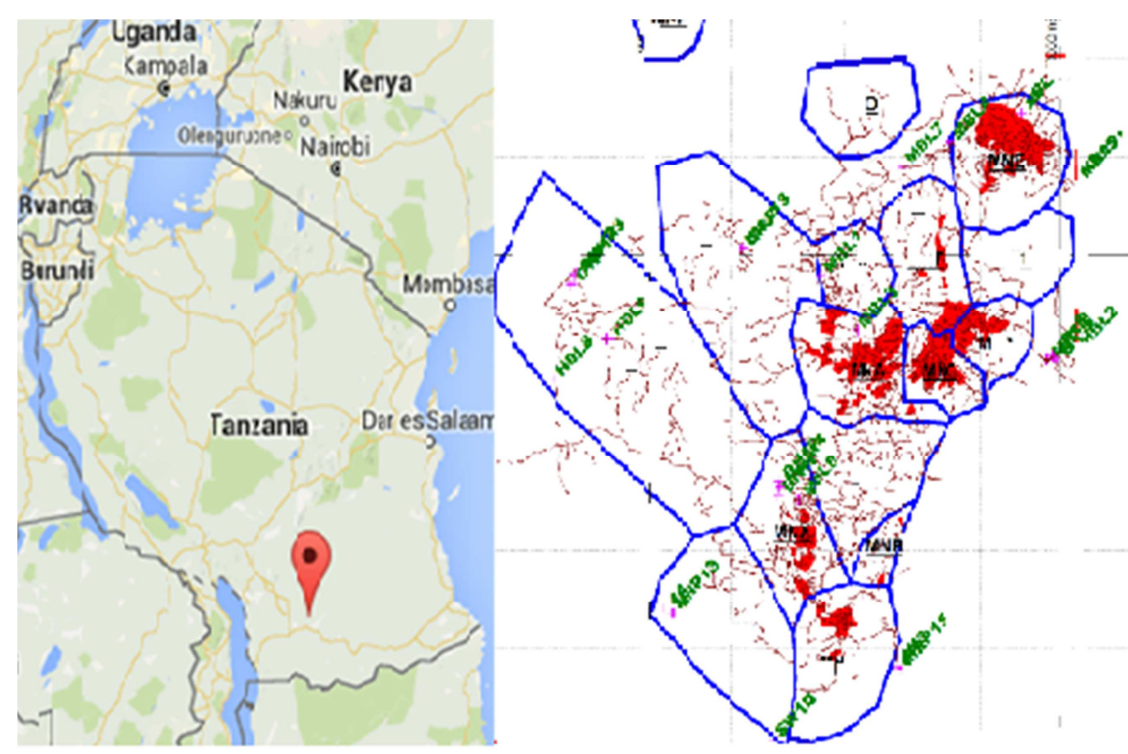

Figure 1. Map of Tanzania with the location of MRP (left) and sketch of sampling points for surface water and groundwater (right). The uranium ore deposits are shaded in red, and the sampling points are indicated by green markers.

\subsection{Sample Collection and Pre-treatment}

Water samples were collected from seven rivers: Naruwale $(6 \mathrm{~km})$, (Ligombe $(11 \mathrm{~km})$, Orogwe $(15 \mathrm{~km})$, Msawati $(36$ $\mathrm{km})$, Mwili (50 km), Mtindiwale (46 km), and Nakatope (48 $\mathrm{km})$. The distances of the river from the perimeter of the MRP concession are given in brackets. These rivers flow through the MRP concession and are used by villagers for domestic consumption and fishing. In addition, groundwater samples were collected from boreholes inside the concession and offsite. To avoid the influence of the rainy season on activity concentrations, a total of 94 water samples from 47 different locations summarized in Table 1 were collected during the dry season between May and September 2014. The samples were collected in one litre transparent polyethylene bottles, which were thoroughly washed with distilled water before transport to the sampling locations. In order to ensure that the samples were kept free from crosscontamination, the pre-cleaned sampling bottles and bailer were thoroughly rinsed with water from the sampling source prior to sample collection. Samples were collected from below the water surface in order to collect representative samples of the activity concentration in a river or a borehole. At each sampling point, two one-litre samples were collected in polyethylene bottles. To prevent bacterial activity and adsorption of radionuclides onto the walls of the sample container, samples were acidified with $2 \mathrm{~mL}$ of nitric acid to $\mathrm{pH}<2$. The pre-treated samples were filtered $(0.45 \mu \mathrm{m})$ to remove particulates with the assumption that radionuclides 
are dissolved and not in a particulate fraction [20]. The filtrates were packed separately in plastic vials, sealed, and labelled with sample date and location before being stored in a cooler at a temperature of about $4^{\circ} \mathrm{C}$. The samples were then transferred to a refrigerator that was also $4^{\circ} \mathrm{C}$ until they were transported to the analytical laboratory at the Nuclear and Technological Institute (ITN) in Portugal. Each sampling point was georeferenced using a Global Positioning System (GPS) model Garmin 75 ${ }^{\mathrm{TM}}$ [21] and recorded in a log book.

Table 1. GPS coordinates of 42 sampling locations for surface and groundwater in the vicinity and 5 locations in concession area.

\begin{tabular}{|c|c|c|c|c|c|c|c|c|c|c|c|}
\hline \multicolumn{4}{|c|}{ Groundwater in the vicinity } & \multicolumn{4}{|c|}{ Surface water in the vicinity } & \multicolumn{4}{|c|}{ Ground water in the concession } \\
\hline Locations & SN & Northings & Eastings & Locations & SN & Northings & Eastings & Locations & SN & Northings & Eastings \\
\hline $\mathrm{BH} 2 \mathrm{~B}$ & 2 & $37 \mathrm{~L} 0232200$ & 8890109 & MRP8 & 2 & 37L0239677 & 8887855 & S1 & 2 & 37L0237542 & 8888890 \\
\hline $\mathrm{BH} 4 \mathrm{~A}$ & 2 & $37 L 0230319$ & 8882798 & MRP13 & 2 & $37 \mathrm{~L} 0232250$ & 8890145 & S2 & 2 & 27L0235679 & 8887826 \\
\hline BH5A & 2 & $37 \mathrm{~L} 0233126$ & 8885087 & MRP14 & 2 & 37L0233182 & 8885255 & S3 & 2 & 27L0234895 & 8884073 \\
\hline BH5B & 2 & $37 \mathrm{~L} 0233140$ & 8885367 & MRP15 & 2 & 37L0236080 & 8881586 & S4 & 2 & 27L0237226 & 8885415 \\
\hline BH3 & 2 & 37L0235989 & 8881609 & MRP16 & 2 & 37L0230489 & 8882699 & S6 & 2 & 27L0237217 & 8887638 \\
\hline ВН30 & 2 & 37L0239874 & 8887885 & MRP23 & 2 & 37L0228199 & 8889639 & & & & \\
\hline HDL2 & 2 & 37L0239796 & 8887938 & MRP24 & 2 & 37L0240409 & 8891490 & & & & \\
\hline HDL8 & 2 & 37L0227608 & 8887464 & SW1U & 2 & 37L0232976 & 8880136 & & & & \\
\hline HDL9 & 2 & $37 \mathrm{~L} 0228956$ & 8888266 & SW1D & 2 & 37L0232976 & 8880139 & & & & \\
\hline HDL15 & 2 & 37L0239012 & 8892875 & SW2U & 2 & 37L0229538 & 8877601 & & & & \\
\hline MB2 & 2 & $37 \mathrm{~L} 0234000$ & 8801002 & SW2D & 2 & $37 \mathrm{~L} 0229512$ & 8877624 & & & & \\
\hline MBL1 & 2 & 37L0234153 & 8889570 & SW3U & 2 & 37L0227941 & 8874697 & & & & \\
\hline MBL2 & 2 & 37L0240380 & 8888047 & SW3D & 2 & 37L0227913 & 8875007 & & & & \\
\hline MBL3 & 2 & 37L0235004 & 8888447 & SW4U & 2 & $37 \mathrm{~L} 0223240$ & 8867535 & & & & \\
\hline MBL4 & 2 & 37L0237288 & 8892284 & SW4D & 2 & 37L0213216 & 8867527 & & & & \\
\hline MBL5 & 2 & 37L0240397 & 8891490 & SW5U & 2 & 37L0209629 & 8861303 & & & & \\
\hline MBL6 & 2 & 37L0239012 & 8892878 & SW5D & 2 & 37L0209618 & 8861304 & & & & \\
\hline MBL7 & 2 & 37L0236143 & 8891776 & SW6U & 2 & 37L0206213 & 8860975 & & & & \\
\hline MBL8 & 2 & 37L0233602 & 8884984 & SW6D & 2 & $37 \mathrm{~L} 0209213$ & 8860986 & & & & \\
\hline GWS1 & 2 & 37L0228061 & 8889395 & SW7U & 2 & 37L0207694 & 8860501 & & & & \\
\hline GWS2 & 2 & 37L0228139 & 8889592 & SW7D & 2 & 37L0207700 & 8860559 & & & & \\
\hline
\end{tabular}

*SN standard for the number of samples in each location

\subsection{Radioactivity and Concentration Ratios}

The analysis of the water samples was conducted according to standards for low level alpha spectrometry [22]. The low background alpha spectrometer has a resolution of $20 \mathrm{keV}$ (FWHM) and a $450 \mathrm{~mm}^{2}$ silicon surface area detector. Spectra were analysed with the OctetePlus ${ }^{\circledR}$ software [23]. In accordance with this methodology, prior to analysis the water samples were spiked with tracers of the analytes to quantify the chemical yield fraction of the analyte. The spiked sample was then evaporated to dryness to reduce the volume [22, 24]. The residue was digested with nitric acid and then passed through an anion exchange column with hydrochloric acid to separate the radionuclides from interfering elements, including those that would cause a decreased yield and reduce the resolution of the alpha energy peaks. Sources of extracted and purified uranium, radium, and thorium were then electrodeposited onto clean stainless steel discs in a Teflon ${ }^{\mathrm{TM}}$ cell with a platinum wire as an anode for alpha counting under vacuum. To lessen the effect of build-up of background activity by alpha recoil, the detector-planchet distance was optimised and counted for

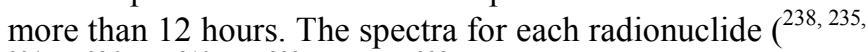
${ }^{234} \mathrm{U},{ }^{226} \mathrm{Ra},{ }^{210} \mathrm{Po},{ }^{232} \mathrm{Th}$, and ${ }^{228} \mathrm{Ra}$ ) in a sample was acquired on a multichannel analyser (MCA). The peak counts generated on the MCA were analysed using the EG\&G Ortec maestro emulation software incorporated with the detection system. A qualitative and quantitative analysis of activity concentration $\left(\mathrm{SA}_{\mathrm{i}}, \mathrm{mBqL}^{-1}\right)$ of radionuclides in the filtered (0.45 um) surface and groundwater samples obtained offsite and inside the MRP concession area were estimated according to Equation 1.

$$
S A=\frac{C_{i}}{\eta \cdot t_{v} \cdot R_{c} \cdot F_{c} \cdot V_{s}}
$$

In this equation, $\mathrm{V}_{\mathrm{s}}$ and $\mathrm{C}_{\mathrm{i}}$ are volume of the sample and counts of the $i^{\text {th }}$ radionuclide in the sample, while $\eta$ denotes detection efficiency, $t_{v}$ the live time in seconds of the collection, $\mathrm{R}_{\mathrm{c}}$ the chemical recovery, and $\mathrm{F}_{\mathrm{c}}$ the correction factor for the radionuclide decay.

\subsection{Quality Assurance}

Laboratory quality control programmes were implemented to ensure that the measurements provide accurate and reliable results. The Nuclear and Technological Institute (ITN) laboratory in Portugal has been participating in the various intercomparison Proficiency tests organised by the International Atomic Energy Agency and the European Union [25-26]. An overall accuracy of 5 to $10 \%$ was achieved between the measured values and the recommended certified values.

\subsection{Human Health Radiological Risk}

It is estimated that about 10,000 villagers within the Namtumbo district get their domestic water and consume fish from water in the tributaries of Liwale and Mkuju Rivers that flow through the concession area to their community. For this 
reason, water has been observed to be one of the main dietary sources of exposure to population. Thus, it was important to estimate the radiological risk associated with activity concentrations in both surface and groundwater. The estimation of radiological risk is based on two approaches: calculations of annual effective dose (E) and carcinogenic risk (R). The effective dose was calculated as shown in Equation 2 using specific activity $\mathrm{SA}_{\mathrm{i}}$ obtained in Equation 1 with ${ }^{40} \mathrm{~K}$ excluded (due to short biological half-life), a conversion factor $\mathrm{CF}_{\mathrm{i}}\left(\mathrm{SvBq}^{-1}\right)\left(2.8 \times 10^{-7}, 6.9 \times 10^{-7}, 4.9 \times 10^{-8}\right.$, and $4.5 \times 10^{-8}$ for ${ }^{226} \mathrm{Ra},{ }^{228} \mathrm{Ra},{ }^{234} \mathrm{U}$, and ${ }^{238} \mathrm{U}$, respectively), and a water consumption rate $\left(\mathrm{V}_{\mathrm{w}}\right)$ of 730 litres per year [27-28].

$$
E=\mathrm{V}_{\mathrm{w}} \sum_{\mathrm{i}}^{\mathrm{n}} \mathrm{SA}_{\mathrm{i}} C F_{i}
$$

Lifetime carcinogenic risk was estimated using the specific activity $\mathrm{SA}_{\mathrm{i}}$ from Equation 1; ingestion rate of radionuclide in water $\left(\mathrm{IR}_{\mathrm{w}}\right)$; cancer slope factor $\left(\mathrm{SF}_{\mathrm{i}}\right)$ for a specific radionuclide in water, which is a measure of the likelihood of incremental cancer induction per unit exposure for that radionuclide; exposure frequency in a year (EF); and exposure duration over human lifetime (ED). The perceived total carcinogenic risk $\left(\mathrm{R}_{\mathrm{T}}\right)$ in Equation 3 was estimated by summing the risks obtained for each of the radionuclides found in water [29].

$$
R_{T}=\mathrm{IR}_{\mathrm{W}} \cdot E F \cdot E D \sum_{i=1}^{n} S A_{i} S F_{i}
$$

\section{Results and Discussion}

\subsection{Activity and Concentration Ratios}

\subsubsection{Activity Concentrations in Water}

Activity concentrations of radionuclides in surface and groundwater samples collected in the vicinity of and within the concession area of the MRP were obtained using Equation 1. The activity concentrations of the ${ }^{238} \mathrm{U}$ series $\left({ }^{238} \mathrm{U},{ }^{234} \mathrm{U},{ }^{230} \mathrm{Th}\right.$, and $\left.{ }^{226} \mathrm{Ra}\right)$ are plotted in Figure 2 for each sampling point for groundwater collected in the vicinity (A) and from the concession area (B). Figure 3 is a plot of the activity concentrations found in the surface water samples collected in the vicinity of the MRP.

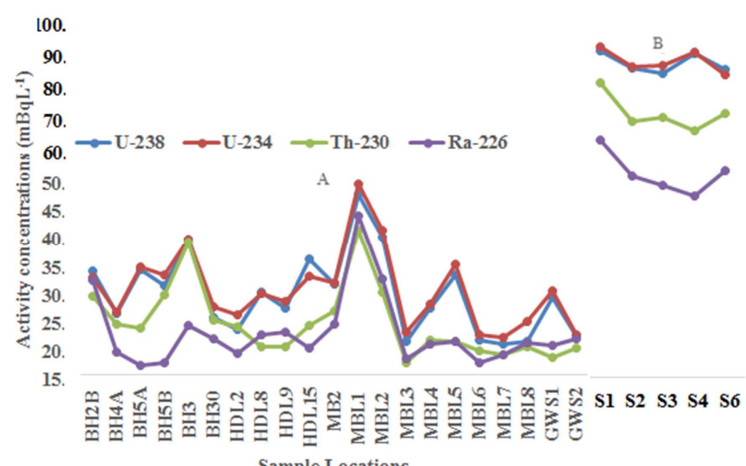

Figure 2. Activity concentrations of ${ }^{238} U,{ }^{234} U,{ }^{230 T h}$, and ${ }^{226} \mathrm{Ra}$ in groundwater samples collected from monitoring boreholes in the vicinity of (A) and within the concession area (B) of the MRP.

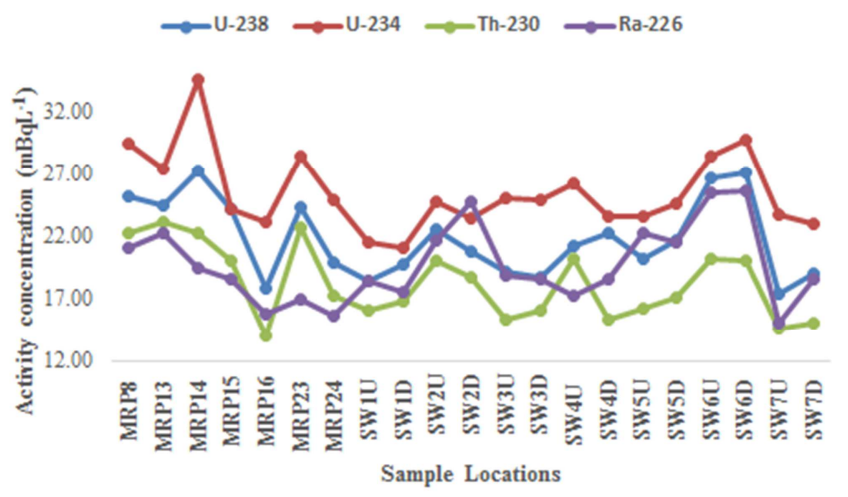

Figure 3. Activity concentrations of ${ }^{238} U,{ }^{234} U,{ }^{230} T h$, and ${ }^{226} R a$ in surface water samples collected in the vicinity of the MRP.

Similarly, the ${ }^{232} \mathrm{Th},{ }^{228} \mathrm{Ra}$, and ${ }^{235} \mathrm{U}$ activity concentrations were plotted in Figure 4 for groundwater in the vicinity of (A) and within the concession area (B), and in Figure 5 for surface water collected in the vicinity of the MRP.

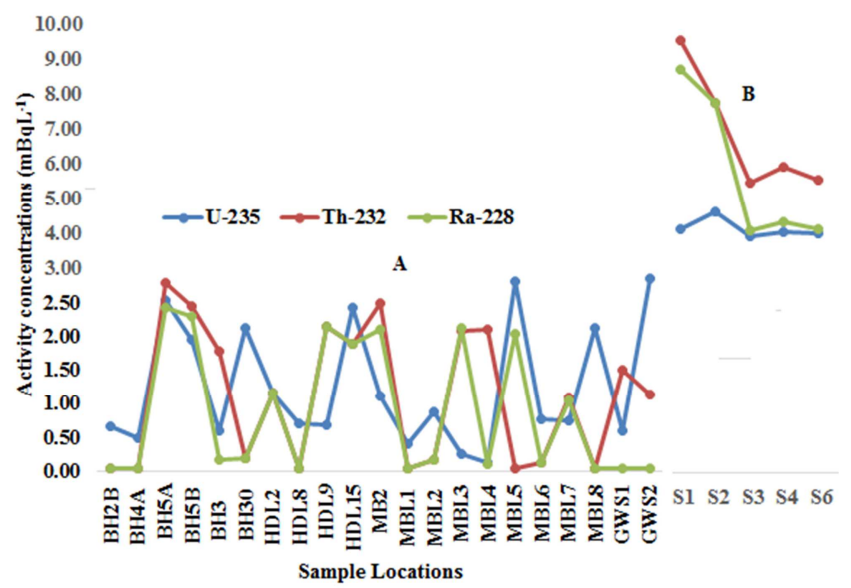

Figure 4. Activity concentrations of ${ }^{235} U,{ }^{232} \mathrm{Th}$, and ${ }^{228} \mathrm{Ra}$ in groundwater samples collected from monitoring boreholes in the vicinity (A) and the concession area of the MRP.

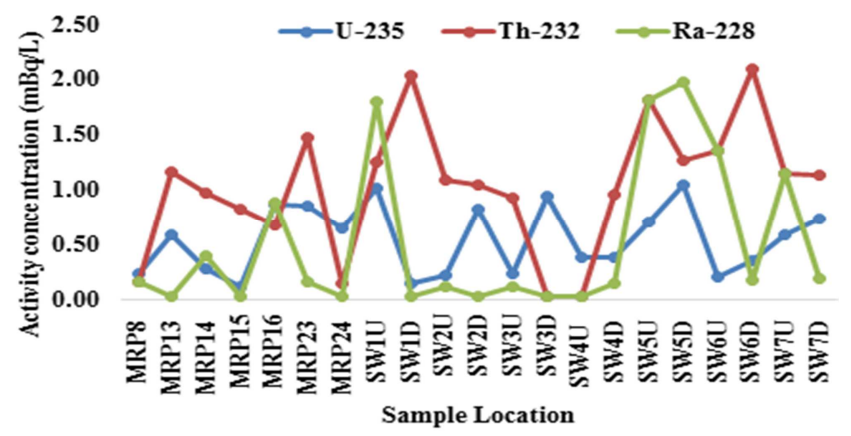

Figure 5. Activity concentrations of ${ }^{235} U,{ }^{232} \mathrm{Th}$, and ${ }^{228} \mathrm{Ra}$ in surface water samples collected in the vicinity of the MRP.

Although ${ }^{232} \mathrm{Th}$ is about 3 to 4 times more abundant in nature than ${ }^{238} U$ [30], we found that the activity concentrations of ${ }^{232} \mathrm{Th}$ (as shown in Figures 4 and 5) were lower than those for ${ }^{238} \mathrm{U}$ (Figures 2 and 3). This is because ${ }^{232} \mathrm{Th}$ is less soluble in water than ${ }^{238} \mathrm{U}$, and therefore less ${ }^{232} \mathrm{Th}$ is released to water from rock. This observation implies that the release of ${ }^{232} \mathrm{Th}$ series from a uranium 
mineralised zone due to uranium mining activities will have less of an impact on water pollution than ${ }^{238} \mathrm{U}$. In groundwater (Figure 2), the range of activity concentrations $\left(\mathrm{mBqL}^{-1}\right)$ of ${ }^{238} \mathrm{U}$ from 20.61 to 47.21 with a mean of $29.31 \pm 7.16$ was comparable to the range of ${ }^{234} \mathrm{U}$ from 21.70 to 49.10 with a mean of $30.17 \pm 6.89$. However, in surface water (Figure 3), the range $\left(\mathrm{mBqL}^{-1}\right)$ of ${ }^{238} \mathrm{U}$ from 17.33 to 27.24 with a mean of $21.77 \pm 3.11$ was much lower than the range of ${ }^{234} \mathrm{U}$ from 21.06 to 34.43 with a mean of $25.44 \pm 3.16 \mathrm{mBqL}^{-1}$. It is likely that this pattern occurred because ${ }^{238} \mathrm{U}$ and ${ }^{234} \mathrm{U}$ were in secular equilibrium in groundwater and dis-equilibrium in surface water, as has already been discussed in the literature [31-34]. In groundwater (Figure 2), ${ }^{226} \mathrm{Ra}$ was comparatively lower than ${ }^{238} \mathrm{U}$ and ${ }^{234} \mathrm{U}$, partly because ${ }^{226} \mathrm{Ra}$ is less soluble in water than ${ }^{238} \mathrm{U}$ and ${ }^{234} \mathrm{U}$ and therefore less of it dissolves into groundwater from rock. The activity concentrations of ${ }^{234} \mathrm{U}$ and ${ }^{238} \mathrm{U}$ in surface water were slightly different because of a lower residence time to set secular equilibrium between ${ }^{234} \mathrm{U}$ and ${ }^{238} \mathrm{U}$. Comparing the activity concentrations in Figures 2 through 5, it is evisdent that activity concentrations in water for different radionuclides at Mkuju River are site-specific and were elevated in groundwater samples collected from the concession area.

Figures 2-5 also show that the activity concentrations of the investigated radionuclides from surface and groundwater sources are comparable to values of radionuclides in drinking water for different countries in the world and significantly lower than the activity concentrations that would trigger a recommended dose constraint of $0.1 \mathrm{mSv} \mathrm{y}^{-1}$ [35]. Based on the practical fact that mining pits are often filled with water during mining operations, pumping of mine water to the environment to dewater the mine may inevitably result to enhanced concentrations of radionuclides in water in the area. In order to recognise the radiological impact of such discharges during routine uranium mining operations, the current values could serve as reference of the quality of drinking water in in the area during and after the mining operations.

\subsubsection{Activity Concentration Ratios}

As described in the literature, isotopic concentrations of daughters normalised to concentrations of their respective parents e.g., ${ }^{238} \mathrm{U}$ and ${ }^{232} \mathrm{Th}$, have been found to produce ratios that indicate the intrusions of radionuclide pollutants into local rivers [36-37]. Indeed, respective ratios of isotopes from these parents are being used as isotopic fingerprints to identify intrusion of water during and after anthropogenic activities in the concession to water bodies in the surrounding area.

As such, the activity concentrations obtained using Equation 1 were used to establish ratios of ${ }^{234} \mathrm{U} /{ }^{238} \mathrm{U}$, ${ }^{226} \mathrm{Ra} /{ }^{238} \mathrm{U}$, and ${ }^{232} \mathrm{Th} /{ }^{238} \mathrm{U}$, which are plotted in Figure 6 for groundwater and Figure 7 for surface water collected in the vicinity of the project. In cases where the concentration of ${ }^{232} \mathrm{Th}$ was below the detection limit, we used a value of onehalf of the minimum detection limit in the calculation of activity ratio to avoid missing data points in the plots [38-39]. As shown in Figure 6, it is apparent that the activity ratios of ${ }^{234} \mathrm{U} /{ }^{238} \mathrm{U}$ in groundwater, as expected, vary from unity at equilibrium in four locations where water is almost stationary (BH2B, BH3, HDL8, and HDL15) to a maximum value of 1.16 at location MBL8. A value greater than one for groundwater is an indication that there is not equilibrium between the daughter $\left({ }^{234} \mathrm{U}\right)$ and parent $\left({ }^{238} \mathrm{U}\right)$, and it is plausible that water is not stationary. Similar analysis of Figure 7 shows that surface water has a wider range of ${ }^{234} \mathrm{U} /{ }^{238} \mathrm{U}$ activity ratios from 1.07 to 1.37 . The activity ratio is unity where water is almost stationary (MRP15) and is greater than one for points where movement of water bodies is moderate (MRP14, MRP16, MRP24, SW4U, and SW7D) or substantial (SW3U, SW3D, and SW7U). Ratios of ${ }^{234} \mathrm{U} /{ }^{238} \mathrm{U}$ greater than unity indicate that ${ }^{234} \mathrm{U}$ is more soluble and preferentially transported by water in comparison to ${ }^{238} \mathrm{U}$, as already reported elsewhere [40-41]. Since the concentration of ${ }^{238} \mathrm{U}$ used to calculate the concentration ratios ${ }^{226} \mathrm{Ra} /{ }^{238} \mathrm{U}$ and ${ }^{234} \mathrm{U} /{ }^{238} \mathrm{U}$ for a location is common to both, the observed difference in concentration ratio values could simply reflect that the solubility of ${ }^{226} \mathrm{Ra}$ is lower than ${ }^{234} \mathrm{U}$. The observed difference in the ratio of ${ }^{232} \mathrm{Th} /{ }^{238} \mathrm{U}$ compared to the other activity concentration ratios indicates that ${ }^{232} \mathrm{Th}$ is much less leachable into water than ${ }^{234} \mathrm{U},{ }^{238} \mathrm{U}$, or ${ }^{226} \mathrm{Ra}$.

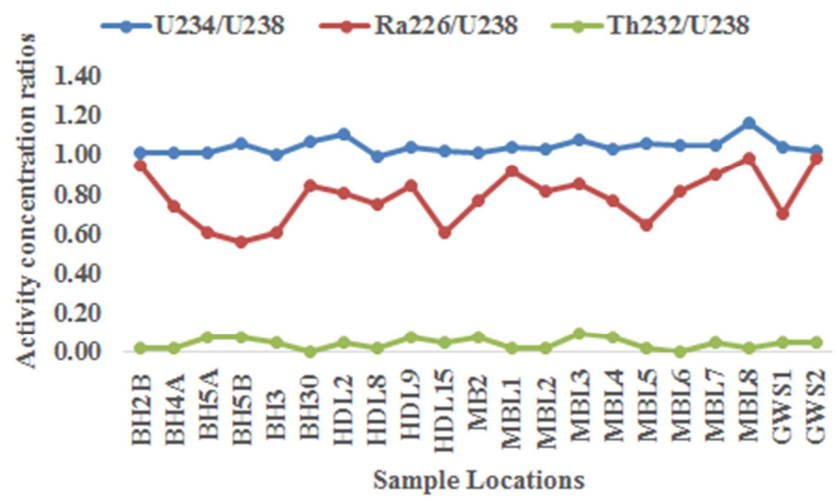

Figure 6. ${ }^{234} U{ }^{238} U,{ }^{226} R a{ }^{238} U$, and ${ }^{232} T h{ }^{238} U$ activity concentration ratios for groundwater in the vicinity of the MRP.

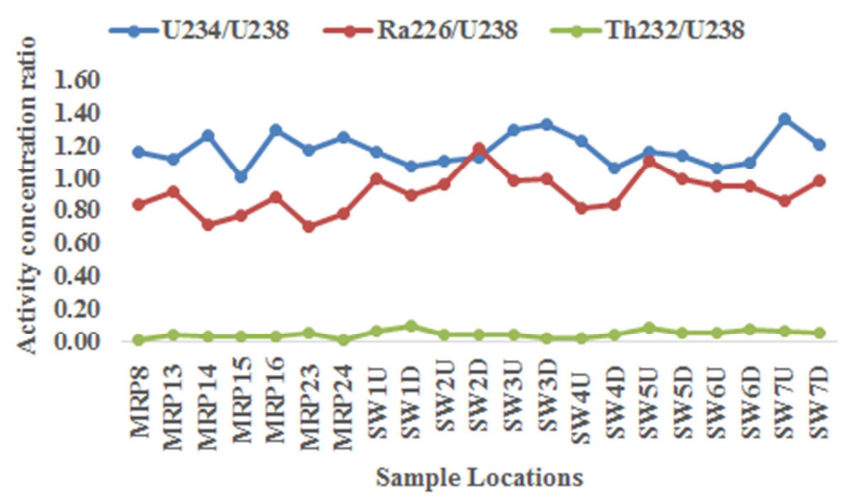

Figure 7. ${ }^{234} U{ }^{238} U,{ }^{226} R a{ }^{238} U$, and ${ }^{232} T h{ }^{238} U$ activity concentration ratios for surface water in the vicinity of the MRP. 


\subsubsection{Prediction of Pollution Using Activity Concentration Ratios}

Our aim in conducting this work was to identify and establish site-specific indicators that could be used to monitor effluents containing radioactive materials from the concession into water bodies in the vicinity of the MRP during and after mining operations. Since uranium mining has not yet begun, these indicators can serve as baseline data for subsequent monitoring of pollution during and after uranium mining activities. Because uranium mining will be conducted in locations where there are high concentrations of ${ }^{238} \mathrm{U}$ and ${ }^{232} \mathrm{Th}$ and their progenies, the desired indicators for pollution during mining were tested by conducting the theoretical exercise of taking a small amount of water $(10 \mathrm{~mL})$ from location S1 in the concession area that has the highest concentration of ${ }^{238} \mathrm{U}$ and ${ }^{232} \mathrm{Th}$ (Figure 2) and mixing this with a substantial amount of surface and groundwater $(1 \mathrm{~L})$ in the vicinity. In this test we calculated the activity concentration ratios for ${ }^{234} \mathrm{U} /{ }^{238} \mathrm{U}$ after mixing using the activity concentrations $\left(A_{N}\right)$ of radionuclides obtained from Equation 4:

$$
A_{N}=\mathrm{A}_{\mathrm{V}} \div \frac{A_{C \max } 0.01}{1.01}
$$

Where: $A_{v}$ is the activity concentration of radionuclide $\left(\mathrm{mBqL}^{-1}\right)$ in water in the vicinity of the project obtained using Equation 1, $\mathrm{A}_{\mathrm{Cmax}}$ is the activity concentration of radionuclide $\left(\mathrm{mBqL}^{-1}\right)$ in water within the concession of the project obtained using Equation 1, 0.01 L is a small volume of water released from the concession area to mix with water in the vicinity of the project and $1.01 \mathrm{~L}$ is the total volume of water after mixing.

The ${ }^{234} \mathrm{U} /{ }^{238} \mathrm{U}$ activity concentration ratio in groundwater in the vicinity of the MRP before the hypothetical discharge of pollutant into water ranged from 0.91 to 1.16 with average of $1.04 \pm 0.05$, and after discharge of $10 \mathrm{~mL}$ of water from the project, the activity concentration ratio ranged from 0.96 to 1.16 with average of $1.03 \pm 0.02$. The activity concentration ratio in surface water in the vicinity of the MRP before the hypothetical discharge of pollutant into water ranged from 1.07 to 1.37 with average of $1.18 \pm 0.10$, and after a discharge of $10 \mathrm{~mL}$ of water from the project, the activity concentration ratio ranged from 1.00 to 1.35 with average of $1.13 \pm 0.07$. Figures 8 and 9 show that the mean activity concentration ratios for both ground and surface water before the hypothetical mixing were higher than the concentration ratios after mixing. After mixing, the variability of activity ratios is less pronounced for groundwater (Figure 8) than for surface water (Figure 9). As illustrated in Figure 8, for groundwater the mean activity concentration decreased by $0.9 \%$ from $1.04 \pm 0.5$ to $1.03 \pm 0.2$, compared to surface water (Figure 9) where the activity concentration ratio decreased by $4.2 \%$ from $1.18 \pm 0.10$ to $1.13 \pm 0.07$. These deviations indicate that the response of the activity concentration ratio to the mixing of water is about four times higher for surface water than for groundwater, which suggests that the activity concentration ratio for surface water could be a better baseline reference for subsequent monitoring of pollution during and after the mining operation.

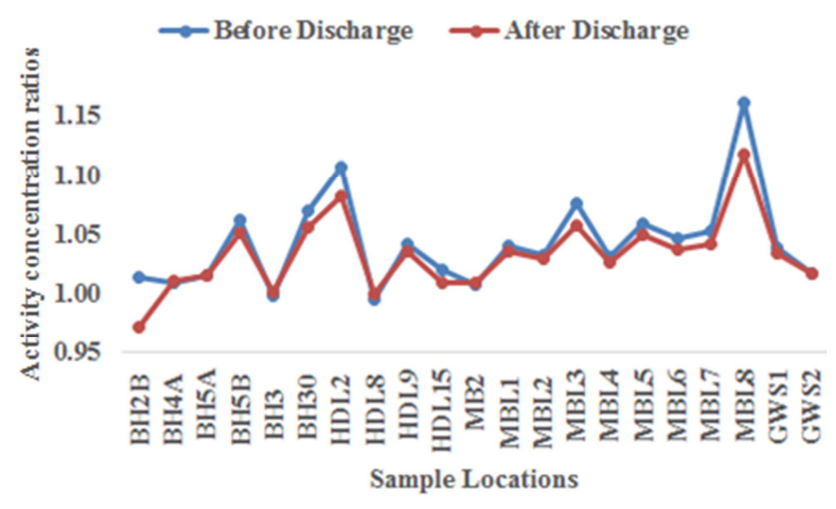

Figure 8. ${ }^{234} U^{238} U$ activity concentration ratio for groundwater in the vicinity of the MRP before and after discharge of $10 \mathrm{~mL}$ of water from the concession.

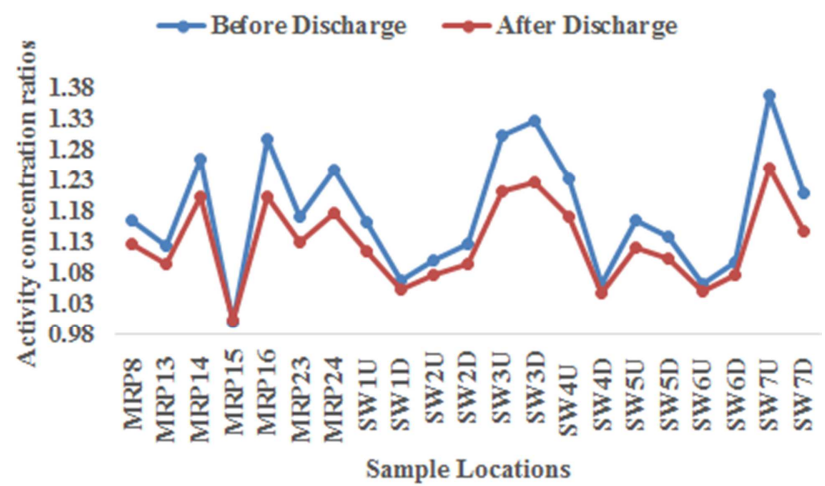

Figure 9. ${ }^{234} U /^{238} U$ activity concentration ratio for surface water in the vicinity of the MRP before and after discharge of $10 \mathrm{~mL}$ of water from the concession.

\subsection{Assessment of Human Health Radiological Risk}

\subsubsection{Annual Effective Dose}

The annual effective dose (E) as an indicator of radiological risk to adults via consumption of drinking water was obtained using activity for the individual radionuclides $\left({ }^{238} \mathrm{U},{ }^{234} \mathrm{U},{ }^{235} \mathrm{U},{ }^{230} \mathrm{Th},{ }^{226} \mathrm{Ra},{ }^{210} \mathrm{Po},{ }^{228} \mathrm{Ra}\right.$, and $\left.{ }^{232} \mathrm{Th}\right)$ and conversion factors, as indicated in Equation 2. The annual effective doses obtained for groundwater from different locations in the vicinity (A) and within the concession area (B) are presented in Figure 10, and the doses for surface water are presented in Figure 11.

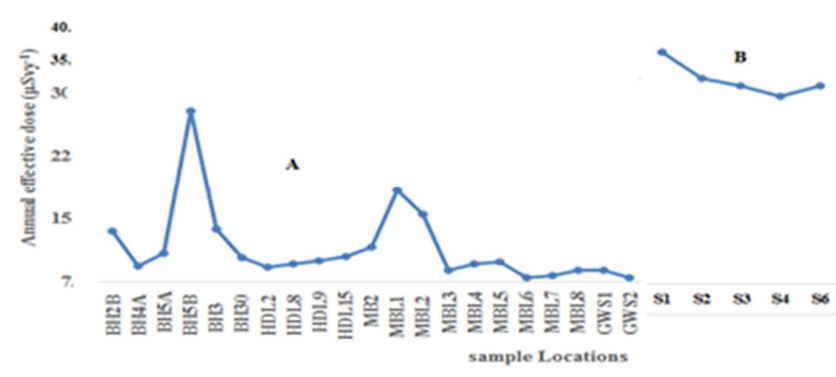

Figure 10. Annual effective doses for adult population drinking groundwater from different locations in the vicinity $(A)$ and within the concession area $(B)$ of MRP. 
As shown in Figure 10, the annual effective dose from exposure to groundwater collected in the vicinity of the project (A) ranged from 7.99 to $27.86 \mu \mathrm{Sv} \mathrm{y}^{-1}$ with average of $11.51 \pm 4.57 \mu \mathrm{Sv} \mathrm{y}^{-1}$, and the annual effective dose from exposure to groundwater from within the concession (B) ranged from 29.34 to $36.20 \mu \mathrm{Sv} \mathrm{y}^{-1}$ with average of $31.90 \pm$ $2.60 \mu \mathrm{Sv} \mathrm{y}^{-1}$. It is evident that the maximum annual effective dose for an adult drinking groundwater in the vicinity of the project is approximately 75 percent of the dose from drinking groundwater from the concession area. However, the maximum annual effective dose in the concession area (before mining the ore) is considerably lower than the exposure limit of $1000 \mu \mathrm{Sv} \mathrm{y}^{-1}$ that is recommended for the public [27]. Since these effective doses based on potential exposure to drinking water were calculated before the commencement of mining operations, they can be used as baseline data in the assessment of water pollution during and after the mining activities.

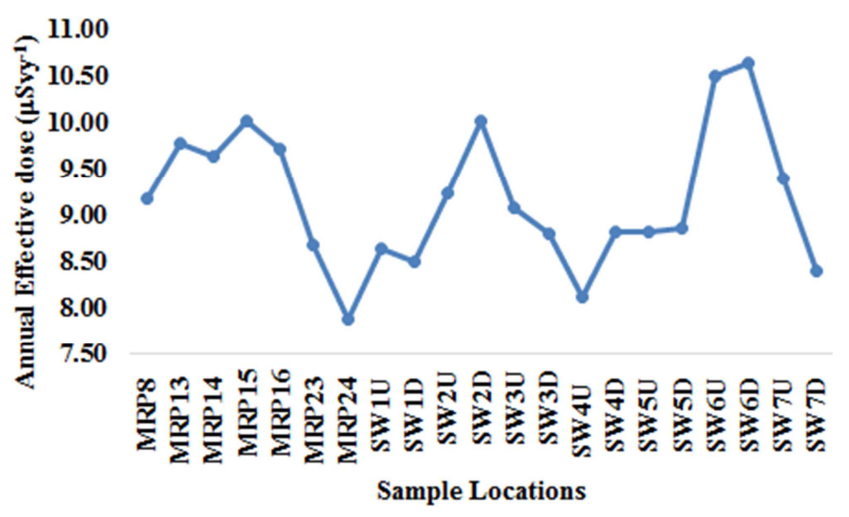

Figure 11. Annual effective doses for adult population drinking surface water from different locations in the vicinity of MRP.

As shown in Figure 11, the annual effective doses from using surface water as drinking water from locations in the vicinity of the project range from 7.89 to $10.64 \mu \mathrm{Sv} \mathrm{y}^{-1}$, with an average of $9.18 \pm 0.75 \mu \mathrm{Sv} \mathrm{y}^{-1}$. The highest annual effective dose of $\sim 11 \mu \mathrm{Sv} \mathrm{y}^{-1}$ at location SW6D is considerably lower than the recommended exposure limit for the public of $1,000 \mu \mathrm{Sv} \mathrm{y}^{-1}$ [27]. Based on these data, it is evident that the radiological risk in terms of internal exposure to people due to both natural surface and groundwater resources in the concession and vicinity of MRP is extremely low, with an overall internal dose that is only a small fraction of the maximum recommended dose to an individual from consumption of foodstuffs [42]. However, the dose from ingestion of surface water in the vicinity is expected to increase if radioactivity from the uranium deposit is released through the mine drainage onto surface or groundwater resources, and therefore there is a need for regulatory surveillance of radionuclide releases and the associated radiological risk.

\subsubsection{Lifetime Carcinogenic Risks}

The lifetime carcinogenic risks to members of the public and workers as a result of consumption of water from offsite and inside the MRP were estimated using Equation 3, and are presented in Figure 12 for groundwater from different locations in the vicinity (A) and within the concession area (B) of MRP. In addition, the lifetime carcinogenic risks to the public from exposure to surface water as drinking water in the vicinity of the MRP are shown in Figure 13. Figure 12 shows that the range of carcinogenic risk attributable to exposure to groundwater in the vicinity of the project (A) ranges from $1.21 \times 10^{-7}$ to $5.32 \times 10^{-7}$ with an average of 2.82 $\mathrm{x} 10^{-7} \pm 8.25 \times 10^{-8}$, which is relatively low in comparison to the risk from the groundwater collected within the concession area (B), which ranges from $6.83 \times 10^{-7}$ to $8.62 \times 10^{-7}$ with an average of $7.67 \times 10^{-7} \pm 8.13 \times 10^{-8}$. The carcinogenic risk from ingestion of surface water from the vicinity of the project (Figure 13) ranges from $2.15 \times 10^{-7}$ to $3.11 \times 10^{-7}$ with average of $2.56 \times 10^{-7} \pm 2.72 \times 10^{-8}$, which is the same order of magnitude to the carcinogenic risks for exposure to groundwater in the concession area and vicinity of the MRP. However, the difference between the two risks is statistically not significant $(\mathrm{p}<0.05)$.

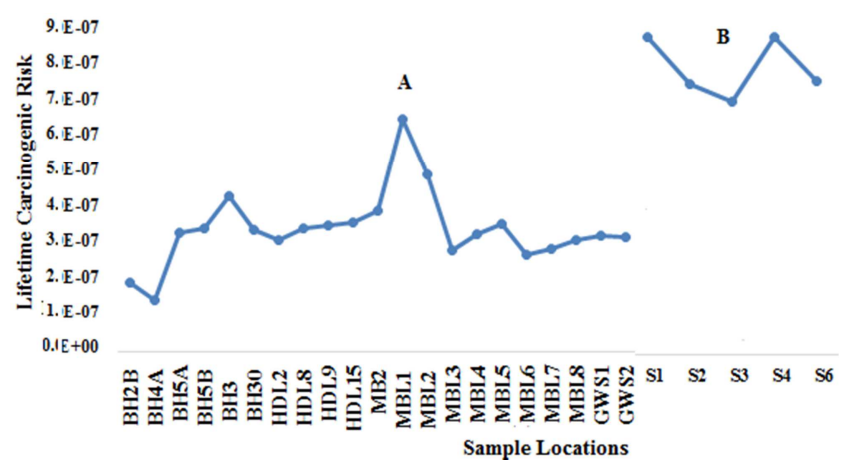

Figure 12. Lifetime carcinogenic risk for drinking groundwater from different locations in the vicinity (A) and concession area (B) of the MRP.

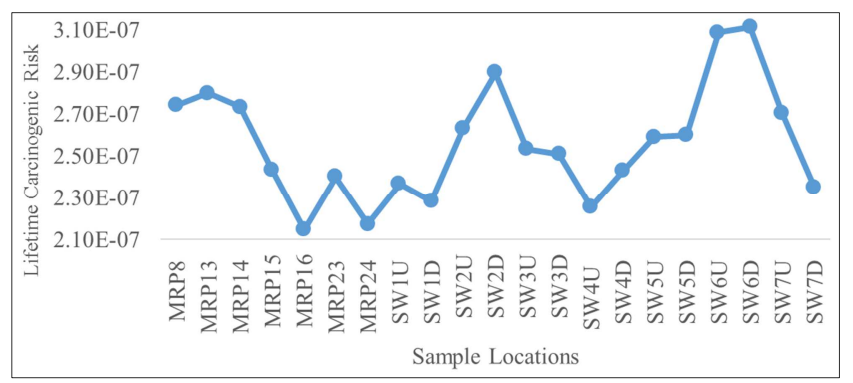

Figure 13. Lifetime carcinogenic risk for drinking surface water from different locations in the vicinity of the MRP.

The assumed range of acceptable excess upper bound lifetime risk of fatal cancers to an individual over 70 years is between $10^{-6}$ to $10^{-4}$ [29], so the lifetime cancer risks reported in this study for surface and groundwater resources do not exceed current lifetime "acceptable risk". This indicates that the probability of excess cancer mortality for an individual who drinks only water from the current water resources obtained offsite and inside the proposed MRP is minimal.

\section{Conclusions}

In this study we determined activity concentrations and the 
associated activity concentration ratios, and human health radiological risks attributed to the consumption of drinking water containing radionuclides. The activity concentrations in water samples from the MRP concession area were found to be higher in groundwater than in surface water. However, the activity concentrations of the investigated radionuclides from each of the water sources were significantly lower than the concentration levels that would approach or exceed the recommended maximum dose of $0.1 \mathrm{mSv} \mathrm{y}^{-1}$ [35]. The annual effective doses and carcinogenic risks related to exposure to water within and around the MRP were significantly below the recommended limits [27]. Further analysis of activity concentration ratios for ${ }^{234} \mathrm{U} /{ }^{238} \mathrm{U}$ and ${ }^{226} \mathrm{Ra} /{ }^{234} \mathrm{U}$ shows higher values in the vicinity of the project than within the concession area, and the ${ }^{234} \mathrm{U} /{ }^{238} \mathrm{U}$ activity ratio demonstrates that this particular ratio is a sensitive indicator for pollution in surface water. Based on the assumption that the concession area is a potential uranium mine, it would enhance the activity concentration and risks levels in the vicinity of the mine when uranium mining processes release radionuclides locked in the deposit into surface or groundwater resources. Therefore regulatory surveillance will be required to monitor discharge into water bodies during and after the uranium mining operations. These findings suggest that the activity concentrations and activity ratios in surface water could be used as baseline data for assessing potential future pollution related to uranium mining at the MRP.

\section{References}

[1] IAEA 2011 Radiation protection and NORM residue management in the production of rare earths from Thorium containing minerals. Safety Report Series No. 68. IAEA, Vienna.

[2] IAEA. 2005. Worldwide marine radioactivity studies (WOMARS): Radionuclide levels in oceans and seas. Vienna: International Atomic Energy Agency: IAEA-TECDOC-1429. http://wwwpub.iaea.org/MTCD/publications/PDF/TE_1429_ web.pdf

[3] Marčiulionienè, D., Mažeika, $\mathrm{J}^{2}$., Lukšienè, B., Jefanova, O., Mikalauskienè, R., Paškauskas, R., 2015. Anthropogenic radionuclide fluxes and distribution in bottom sediments of the cooling basin of the Ignalina Nuclear Power Plant. J Environ Radioact. 145: 48-57. doi: 10.1016/j.jenvrad.2015.03.007.

[4] Togawa, O., Povinec, P. P., Pettersson, H. B. L., 1999. Collective dose estimates by the marine food pathway from liquid radioactive wastes dumped in the Sea of Japan. Science of the Total Environment 238: 241-248.

[5] Aarkrog, A., 2003. Input of anthropogenic radionuclides into the World Ocean. Deep-Sea Research Part II-Topical Studies in Oceanography 50 (17-21): 2597-2606.

[6] Andrews, W. S., Ham, M. E. J., Bennett, L. G. I., Grandmaison, E. W., 2001. Modelling the dispersion of radionuclides released during reactor accidents aboard nuclear-powered vessels. Journal of Radioanalytical and Nuclear Chemistry 248 (3): 657-662.

[7] IAEA, (International Atomic Energy Agency). 2003. Radiation protection and the management of radioactive waste in the oil and gas industry. Safety Report Series No. 34. IAEA, Vienna.

[8] Chalupnik, S., 2002. Radium Leaching from Settling Ponds of Coal Deposits. Journal of Mining Science 38, (5), 473480.

[9] Serena, R, Patrizia, L., Luigi, B., 2005. Health and environmental impacts of a fertilizer plant - Part I: Assessment of radioactive pollution Journal of Environmental Radioactivity 82 167-182.

[10] IAEA, 2013. Radiation protection and management of NORM residues in the phosphate industry. Safety reports series no. 78 . IAEA, Vienna.

[11] Sahu, S. K., Ajmal, P. Y., Bhangare, R. C., Tiwari, M., Pandit, G. G., 2014. Natural radioactivity assessment of a phosphate fertilizer plant area Journal of Radiation Research and Applied Sciences 7 (1) 123-128.

[12] Aellen T. C,, Umbricht, O., Goerlich, W.,. 1993. The analysis of naturally-occurring radionuclides from uranium and thorium decay series in table mineral waters. Sci Total Environ. 130-131: 253-9.

[13] Pietrzak-Flis, Z., Rosiak, L., Suplinskam M. M., Chrzanowski, E., Dembinska, S. 2001. Daily intakes of ${ }^{238} \mathrm{U},{ }^{234} \mathrm{U},{ }^{232} \mathrm{Th}$, ${ }^{230} \mathrm{Th},{ }^{228} \mathrm{Th}$ and ${ }^{226} \mathrm{Ra}$ in the adult population of central Poland. Sci. Total Environ. 273 (1-3): 163-9.

[14] ICRP, 2000, Protection of the public in situations of prolonged radiation exposure. ICRP Publication 82, Pergamum Press, Oxford, United Kingdom.

[15] IAEA, 2006. Assessing the need for radiation protection measures in work involving minerals and raw materials. Safety Report Series No. 49. IAEA, Vienna.

[16] TAEC, (Tanzania Atomic Energy Commission). 2011. The Atomic Energy (Radiation Safety in the Mining and Processing of Radioactive Ores) Regulations 2011.

[17] Act No. 7 of 2003. Acts of Parliament, Tanzania, TZA-2003L-64737. parliament.go.tz/polis/uploads/bills/acts/1454071335-ActNo7-2003.pdf

[18] MSL 2010 Mkuju River Project, Definitive Feasibility Study: Chapter 6 Mining. Tanzania: Downing, Reynard and Associates (Pty) Ltd.

[19] Banzi, F. P., Msaki, P. K., Najat, K. M., 2015, Distribution of heavy metals in soils in the vicinity of the proposed Mkuju uranium mine in Tanzania. Environ and Poll, 1. 4, 3: 42-50.

[20] Anderson RF, Fleisher, MQ Robinson LF, Edwards RL, Hoff JA, Moran SB, van der Loeff MR, Thomas, AL Roy-Barman M, Francois R. 2012 Geotraces inter calibration of ${ }^{230} \mathrm{Th}$, ${ }^{232} \mathrm{Th},{ }^{231} \mathrm{~Pa}$, and prospects for ${ }^{10} \mathrm{Be}$. Limnol Oceanogr: Methods 10: 179-213.

[21] Goddard, C. C. 2002. Measurement of outdoor terrestrial gamma radiation in the Sultanate of Oman. Health Phys. 82: 869-74.

[22] Martin, P., Hancock, G., 1992. Routine analysis of naturally occurring radionuclides in environmental sample by alpha particle spectrometry. Supervising Scientists for the Alligator river region, Research report 7, Australian Government Publishing Service, Canberra. 
[23] Oliveira, J. M., Carvalho, F. P., 2006, A Sequential Extraction Procedure for Determination of Uranium, Thorium, Radium, Lead and Polonium Radionuclides by Alpha Spectrometry in Environmental Samples. Proceedings of the 15th Radiochemical Conference. Czechoslovak Journal of Physics 56 (Suppl. D): 545-555.

[24] Katzlberger, G., Wallner, G., Irlweck, K., 2001. Determination of ${ }^{210} \mathrm{~Pb},{ }^{210} \mathrm{Bi}$ and ${ }^{210} \mathrm{Po}$ in natural drinking water, J Radioanal Nucl Chem. 249: 191-196.

[25] Carvalho, F. P., Oliveira, J. M., Libanio, A., Lopes, I., Ferrador, G., Madruga, M. J. 2005a. Radioactivity in public water supplies in the uranium mining regions in Portugal. Proceedings of the international workshop on environmental contamination from uranium production facilities and remediation measures, held in Lisbon 11-13 Feb 2004, 41-51. International Atomic Energy Agency, Vienna.

[26] Carvalho, F. P., Oliveira, J. M., Madruga, M. J., Lopes, I, Libanio, A, Machado, L. 2005b Contamination of hydrographic basins mining areas of portugal. uranium in the environment, mining aspects and consequences, B. J. Merkel and A. Hasche-Berger eds. Springer-Verlag Berlin Heidelberg: 691-702.

[27] ICRP, 1996. Age-dependent doses to members of the public from intake of radionuclides: Part 5 Compilation of ingestion and inhalation dose coefficients. ICRP Publication 72, Pergamum Press, Oxford, United Kingdom.

[28] WHO, 2008. Guidelines for Drinking Water Quality $3^{\text {rd }}$ edn. Incorporating the First and Second Agenda volume recommendations. Geneva, Switzerland.

[29] USEPA (United States Environmental Protection Agency). 2001. Risk assessment guidance for superfund. Volume III (Part A), Process for conducting probabilistic risk assessment. Washington DC. EPA 540-R-02-002.

[30] Nuccetelli, C., Rusconi, R, Forte, M., 2012. Radioactivity in drinking water: regulations, monitoring results and radiation protection issues. Ann Ist Super Sanità 48 (4) 362-373. doi: 10.4415/ANN_12_04_04.

[31] Kitto, M. E., Kim, M. S. 2005. Naturally occurring radionuclides in community water supplies of New York State. Health Physics. 88 253-260.

[32] Suksi, J., Rasilainen, K., Pitkanen, P. 2006. Variations in
${ }^{234} \mathrm{U} /{ }^{238} \mathrm{U}$ activity ratios in groundwater a key to flow system characterization? Phys Chem Earth. 31 556-571.

[33] Chabaux, F., Bourdon, B., Riotte, J. 2008. U-series geochemistry in weathering profiles, river waters and lakes. Radioactivity in the Environment 13 49-104.

[34] Dias da Cunha, K. M., Henderson, H., Thomson, B. M., Hecht, A. A. 2014. Ground water contamination with ${ }^{238} \mathrm{U},{ }^{234} \mathrm{U},{ }^{235} \mathrm{U}$, ${ }^{226} \mathrm{Ra}$ and ${ }^{210} \mathrm{~Pb}$ from past uranium mining: cove wash, Arizona. Environ Geochem Health. 36 (3): 477-87.

[35] WHO, 2011. Guidelines for Drinking-Water Quality, $4^{\text {th }}$ edn. Geneva, Switzerland. http://whqlibdoc.who.int/publications/2011/9789241548151_e ng.pdf.

[36] Riotte, J., Coischabaux, F., 1999. ${ }^{234} \mathrm{U} /{ }^{238} \mathrm{U}$ Activity ratios in freshwaters as tracers of hydrological processes: The Strengbach watershed (Vosges, France). Geochimica et Cosmochimica Acta, 63 (9): 1263-1275.

[37] Rodrigo, J. F., Casas-Ruiz, M., Vidal, J., Barbero, L, Baskaran, M., Ketterer, M. E., 2014. Application of ${ }^{234} \mathrm{U} /{ }^{238} \mathrm{U}$ activity ratios to investigations of subterranean groundwater discharge in the Cádiz coastal area (SW Spain) Journal of Environmental Radioactivity. 130 68-71.

[38] Ndengerio-Ndossi, J., Cram, G. 2005. Pesticide Residues in table ready foods in Tanzania. Intern $\mathrm{J}$ of Environ Health Research. 15 143-149.

[39] Mohammed, N. K. 2008. Nuclear techniques applied to biological samples from tanzania to monitor the nutritional status of children. PhD Thesis, Faculty of Engineering and Physical Sciences, University of Surrey, UK.

[40] Osmond, J. K., Cowart, J. B., Ivanovitch, M. 1983. Uranium isotopic disequilibrium in ground water as an indicator of anomalies. Int J Appl Radiat Isot. 34: 283.

[41] Dosseto, A., Bourdon, B., Gaillardet, J., Maurice-Bourgoin, L., Allègre, C. J. 2006. Weathering and transport of sediments in the Bolivian Andes: Time constraints from uranium-series isotopes. Earth and Planetary Science Letters. 248: 759-771.

[42] WHO (World Health Organization) 1988 Derived intervention levels for radionuclides in food. Guidelines for application after widespread radioactive contamination resulting from a major radiation accident. Geneva, Switzerland. 